\title{
Lymphadenopathy, splenomegaly, intermittent neutropenia, and acute kidney injury: Questions
}

\author{
Katie Sullivan ${ }^{1} \cdot$ Rose Chami $^{1} \cdot$ Rachel Pearl $^{1,2}$ \\ Received: 25 June 2019 / Revised: 11 July 2019 / Accepted: 23 July 2019 /Published online: 29 August 2019 \\ (C) IPNA 2019
}

Keywords Child $\cdot$ Anemia $\cdot$ Neutropenia $\cdot$ Splenomegaly $\cdot$ Lymphadenopathy $\cdot$ AKI $\cdot$ Hypertension

A 3-year-old female with an 18-month-old history of lymphadenopathy, intermittent neutropenia, and splenomegaly, presented to the emergency department with tachypnea and abdominal distention. Two weeks prior, she had experienced a bilateral purpuric rash, which resolved within a day, joint swelling, and non-specific abdominal pain. Blood work showed anemia $(\mathrm{Hb} 73 \mathrm{~g} / \mathrm{L})$ and neutropenia $\left(1.22 \times 10^{9} / \mathrm{L}\right)$, as well as acute kidney injury, urea at $15.2 \mathrm{mmol} / \mathrm{L}$, and creatinine $(\mathrm{Cr}$ ) at $34 \mu \mathrm{mol} / \mathrm{L}$ (baseline $\mathrm{Cr} 18 \mu \mathrm{mol} / \mathrm{L}$ ). There was no clear evidence of a hemolytic anemia, with a normal haptoglobin of $1.54 \mathrm{~g} / \mathrm{L}$, normal LDH of $724 \mathrm{U} / \mathrm{L}$, and no schistocytes on blood film. Platelet count at presentation was normal at $217 \times 10^{9} / \mathrm{L}$ and remained normal. Her serum albumin was a lower limit of normal at $35 \mathrm{~g} / \mathrm{L}$. Potassium was elevated at $5.7 \mathrm{mmol} / \mathrm{L}$, magnesium at $1.2 \mathrm{mmol} / \mathrm{L}$, and urate at $423 \mu \mathrm{mol} / \mathrm{L}$. Her creatine phosphokinase was normal at $39 \mathrm{U} / \mathrm{L}$.

From an immune standpoint, her ferritin was elevated at $223.5 \mu \mathrm{g} / \mathrm{L}$. C3 and C4 were normal at $1.18 \mathrm{~g} / \mathrm{L}$ and $0.23 \mathrm{~g} / \mathrm{L}$, respectively. IgA was elevated at $2.6 \mathrm{~g} / \mathrm{L}$, as was her $\operatorname{IgG}$ at $21.4 \mathrm{~g} / \mathrm{L}$, but IgM was normal at $0.6 \mathrm{~g} / \mathrm{L}$. ANA was positive at 1:160; anti-dsDNA, ANCA, and anti-GBM were all negative. Of note, her vitamin B12 levels in the serum were very elevated at $>4427 \mathrm{pmol} / \mathrm{L}$ (normal 218-1305 $\mathrm{pmol} / \mathrm{L}$ ).

The answer to this question can be found at https://doi.org/10.1007/ s00467-019-04322-7.

Katie Sullivan

sullivankatiemarie@gmail.com

1 Hospital for Sick Children, Toronto, Canada

2 William Osler Health System, Brampton, Ontario, Canada
Urinalysis was positive for blood, but on microscopy, only 1-2 red blood cells were seen, with $0-1$ white cells and no red cell casts. There was also mild proteinuria, with a protein/ creatinine ratio of $60 \mathrm{mg} / \mathrm{mmol}$ and albumin/creatinine ratio of $25.9 \mathrm{mg} / \mathrm{mmol}$. On examination, the patient's blood pressure was elevated at $123 / 86$, and her respiratory rate (RR) was also increased at 44 . A chest x-ray showed bilateral pleural effusions. There was no rash or evidence of joint swelling at time of presentation. Ultrasound showed splenomegaly and enlarged lymph nodes in the right upper quadrant at $1.3 \mathrm{~cm}$. Her kidneys initially showed normal echogenicity and were normal sizes, of $8.4 \mathrm{~cm}$ on the right and $9 \mathrm{~cm}$ on the left.

Over the course of her admission, the albumin/creatinine ratio increased to $96.6 \mathrm{mg} / \mathrm{mmol}$, serum albumin dropped to a nadir of $29 \mathrm{~g} / \mathrm{L}$, and creatinine peaked at $60 \mu \mathrm{mol} / \mathrm{L}$. Her microscopic hematuria remained persistent. Her hypertension also remained an issue, requiring treatment with furosemide and amlodipine. Due to these features, a renal biopsy was performed.

\section{Questions}

1) What is your differential diagnosis?

2) What is the likely diagnosis?

3) What would you expect to see on renal biopsy?

4) How would you manage the patient?

\section{Compliance with ethical standards}

Conflict of interest The authors declare that they have no conflict of interest.

Publisher's note Springer Nature remains neutral with regard to jurisdictional claims in published maps and institutional affiliations. 